\title{
Computer networks win new funding in Japan
}

Tokyo. Despite the most austere budget in 40 years, Japan's Science and Technology Agency (STA) and the Ministry of International Trade and Industry (MITI) have managed to win large increases in funding for computer networks and computer-related facilities and projects in the budget for the fiscal year 1995, which was finalized at the end of last month.

The new money will result in a significant increase in Japan's contribution to the worldwide Internet system of computer networks, in which Japan has so far been slow to participate.

For the first time since 1955, Japan's overall budget will decrease - by 2.9 per cent - relative to last year because of shortfalls in tax revenue resulting from the prolonged recession. The STA and MITI have therefore done well to win even small rises in their budgets for research and development (see table). The budgets have to be formally approved by the Diet, the Japanese parliament, before coming into effect in April. But in practice they are unlikely to undergo any change.

The STA has obtained an increase of nearly 50 per cent in funding for its interministry computer network, already under construction, which will have a highcapacity backbone network linking Tsukuba science city, Tokyo and the Kansai region encompassing Kyoto and Osaka. The network will be linked to other computer networks in universities and national research institutes run by various ministries, and will also have a high-capacity overseas link.
STA has also has obtained $¥ 2,776$ million (US\$28 million) for a high performance computer system to be used by its various research institutes through the computer network to model phenomena such as molecular interactions and global climate change. The budget includes funds for both software and a supercomputer, although STA has yet to decide where the supercomputer will be located.

MITI has been granted about $¥ 1$ billion (US\$10 million) for computer databases and a new research information centre in Tsukuba science city that will provide outside users access to the ministry's powerful supercomputer centre in Tsukuba.

Until now, the supercomputer centre could only be used by the ministry's 2,500 researchers. But the new centre will be open to users in universities and industry who are participating in MITI projects.

One such project is the Real World Computing (RWC) project, a follow-up to the fifth generation computer project, which gets a 20 per cent boost in its budget, to $¥ 6$ billion. The government's goal is to develop massively parallel computer systems using various approaches, such as optical computing and neural networks.

There is also a significant increase in the budget for STA's human genome project, which will grow to $¥ 2.4$ billion. Japan’s genome researchers were among the first to establish computer networks in Japan in the late 1980 s, and will no doubt benefit from the rapidly expanding networks.

David Swinbanks

\section{HIGHLIGHTS OF JAPAN'S R \& D BUDGET \\ $1995 \%$ change}

(in billion yen: US\$1 = $¥ 100$ )

Ministry of International Trade and Industry Total R \& D budget request $\quad 295.4 \quad+3.8$

Industrial Scientific Technology $24.9 \quad+5.4$

$\begin{array}{lll}\text { New Sunshine Project } & 54.2 \quad+2.7\end{array}$

Real World Computing Project $\quad 6.0 \quad+20.5$

Intelligent Manufacturing $\quad 1.3 \quad+0.1$

System Project

Global Environment Research $\quad 12.5 \quad+4.2$

Unmanned Space Platform $\quad 8.3 \quad-0.3$

$\begin{array}{lll}\text { Research Databases } & 0.8 \quad+46.9\end{array}$

Research Information Center

(new)

NEDO Fellows (new) $\quad 0.4$

NEDO International Grants $\quad 0.9 \quad+3.4$

Japan Key Technology Center $\quad 26.0 \quad 0.0$

Science and Technology Agency

Total R \& D budget $\quad 646.1 \quad+6.8$

Special Promotion Funds $\quad 18.5 \quad+19.3$

Interministry computer network (1.6) +45.5

High Performance Computing $\quad 2.8+1508.7$

$\begin{array}{lll}\text { Space } & 163.9 & +5.0\end{array}$

$\begin{array}{lll}\text { Nuclear Power } & 342.3 & +5.7\end{array}$

(ITER $\quad 8.3+3.7$ )

$\begin{array}{lll}\text { (SPring-8 } 15.1 & +37.3 \text { ) }\end{array}$

Human Genome $\quad 2.4 \quad+26.3$

$\begin{array}{lll}\text { Human Frontier Science } & 3.5 * & -2.8\end{array}$

Programme

Frontier Research System $\quad 3.9 \quad+19.9$

STA Fellowships $\quad 2.2+15.8$

* includes $¥ 1.4$ billion from MITI

\section{UK researchers highlight lack of funds for overheads}

London. David Hunt, Britain's minister for science, last week promised to raise the question of whether English universities are using enough of their funds to cover the overhead costs of biomedical departments with Gillian Shephard, the secretary of state for education, and with the Higher Education Funding Council for England(HEFCE).

The promise was made in response to concern voiced by 12 biomedical research scientists, all funded by the Wellcome Trust, who have come (or returned) from abroad to work in Britain. They attended a meeting with both Hunt and Virginia Bottomley, the secretary of state for health.

The main purpose of the meeting was to discuss why, at least in some research fields - and with the support of private funding - Britain can demonstrate a clear 'braingain' that stands in contrast to the highly publicized 'brain-drain' of recent years.

But both the scientists and the officials of the Wellcome Trust, which this year expects to provide around $£ 200$ million for research, also used the occasion to tell Hunt of the problems that arise from the fact that universities receive money from the government through the funding councils on a block grant basis.

The amount of money awarded to a particular university depends on many factors, including its research income and the quality of its research. But a university is free to spend the money it receives as it chooses.

Julian Jack, a governor of the Wellcome Trust, says that some universities do not pass enough of this money on to the departments that attract the research income. As a result, where charities such as the Wellcome Trust - which do not provide overhead costs - fund the research, a lack of infrastructure support provided by the university means that departments are running at a deficit, or curtailing their research.

Professor John Bell, a Canadian who moved to Britain from Stanford University in California, and who is now chairman of the Nuffield department of clinical medicine at the University of Oxford, says that the lack of adequate government support for research overheads is "singularly the biggest problem" facing most university biomedical research departments.

Nevertheless, the scientists who met Hunt and Bottomley listed several attractions of biomedical research in the United Kingdom. These included the availability of long-term support - particularly in grants from the Medical Research Council (MRC) and the Wellcome Trust - and the opportunities for collaboration resulting from the proximity of Europe.

Other factors include a smaller and more cohesive research community than that in the United states, and the fact that the $\mathrm{Na}-$ tional Health Service makes it easy to combine academic research with clinical work and access to patients and patient records.

But, despite the advantages, all the scientists who spoke to Hunt agreed that a major disadvantage is the lack of international competitiveness of UK salaries. According to Bell, this is symptomatic of the low status attached to scientists in the United Kingdom.

Maggle Verral 